\title{
EXPERIMENTAL STUDY ON SHEAR BEHAVIOR OF RC BEAMS USING U-SHAPED UFC PERMANENT FORMWORK WITH SHEAR KEYS AND BOLTS
}

\author{
Puvanai WIROJJANAPIROM ${ }^{1}$, Koji MATSUMOTO², Katsuya KONO$^{3}$ \\ and Junichiro NIWA 4 \\ ${ }^{1}$ Member of JSCE, Ph.D. Candidate, Dept. of Civil Eng., Tokyo Institute of Technology \\ (2-12-1-M1-17 O-okayama, Meguro-ku, Tokyo 152-8552, Japan) \\ E-mail: wirojjanapirom.p.aa@m.titech.ac.jp \\ ${ }^{2}$ Member of JSCE, Assistant Professor, Dept. of Civil Eng., Tokyo Institute of Technology \\ (2-12-1-M1-17 O-okayama, Meguro-ku, Tokyo 152-8552, Japan) \\ E-mail: matsumoto.k.ar@m.titech.ac.jp \\ ${ }^{3}$ Member of JSCE, Research Scientist, Research and Development Center, Taiheiyo Cement Corporation \\ (2-4-2, Osaku, Sakura-shi, Chiba 285-8655, Japan) \\ E-mail: katsuya_kono@taiheiyo-cement.co.jp \\ ${ }^{4}$ Fellow of JSCE, Professor, Dept. of Civil Eng., Tokyo Institute of Technology \\ (2-12-1-M1-17 O-okayama, Meguro-ku, Tokyo 152-8552, Japan) \\ E-mail: jniwa@cv.titech.ac.jp
}

\begin{abstract}
UFC is one of the cementitious materials which have outstanding properties such as more than 200 MPa compressive strength, high ductility and durability. The permanent formwork for RC structures is one of the promising applications of UFC. This research is aimed to investigate the shear behavior of RC beams using a U-shaped UFC permanent formwork. Eight RC beams using a U-shaped UFC permanent formwork were tested by four-point bending test. The experimental parameters were the presence of shear keys at the internal surface of a UFC U-shaped permanent formwork, presence of screws and bolts, thickness of formwork, shear span to effective depth ratio and presence of stirrups. The experimental results indicated that a U-shaped UFC permanent formwork enhanced the shear capacity of RC beams more than twice compared to normal RC beams. In addition, the shear resistance mechanisms were investigated. By using a UFC formwork with shear keys and screwed bolts, the UFC formwork intercepted widening of diagonal cracks inside a RC part. Finally, the shear carried by a UFC permanent formwork was investigated. The proposed calculation method can provide a good agreement with the experimental values.
\end{abstract}

Key Words : UFC, permanent formwork, shear keys, screws and bolts, shear resisting mechanism

\section{INTRODUCTION}

In order to mitigate the seismic risk and social damage, the improvement of seismic performance of infrastructures is required. Moreover, it is well known that the shear failure of a reinforced concrete (RC) structure is sudden and brittle in nature. It is more dangerous than the flexural failure because it gives no warning prior to failure. Consequently, since the 1995 Great Hanshin earthquake, the standards specification of Japan Society of Civil Engineers (JSCE) for design of concrete structures ${ }^{1)}$ has started to be revised. As a result, in order to prevent the shear failure in RC members, many structures have required a large amount of shear reinforcing bars and concrete became difficult to be filled up in casting. This demand can be achieved by the construction method by using recently developed Ultra High Strength Fiber Reinforced Concrete (UFC) ${ }^{2)}$.

UFC is an advanced cementitious composite material which has been rapidly developed for recent years and implemented through the bridge construction in the world ${ }^{3)-5)}$. Through the proper "Ultra high" strength parameters, this material provides with characteristic values in excess of $150 \mathrm{MPa}$ in the compressive strength and $5 \mathrm{MPa}$ in the tensile strength with high bending toughness and ductility due to the existence of steel fibers ${ }^{6)}$. Kakei et al. ${ }^{7)}$ 
concluded that the shear carrying capacity of UFC beams was significantly enhanced by bridging effect of steel fibers contained in UFC. Furthermore, with close-packed micro-structures, UFC has excellent durability properties such as resistance to chloride ion attacks and abrasion. These advantages combined together make UFC suitable for many engineering applications and among of them a permanent formwork is possible.

A number of composite systems have been developed, where UFC is used as structurally integrated permanent formwork for concrete structure.

The definition for permanent formwork derived from CIRIA C558 ${ }^{8}$ is the structural elements of whatever materials that is used to contain the placed concrete, mold it to the required dimensions and remain in place for the life of the structure. These permanent formwork systems are maximizing the benefits of UFC and concrete while simplifying the construction process. A permanent formwork is first fabricated, and the construction process then only involves the casting of plain concrete into the in situ permanent formwork. Besides the improvement of construction competency such as reducing the on site's needed skill level, speeding up erection times and etc, construction wastes are also reduced in comparison of using wooden formwork.

Considerable researches have been conducted on reinforced concrete structures with using UFC permanent formwork; Shirai et al. ${ }^{9)}$ presented the strengthening of bridge piers and reported that UFC formwork left in-place increased durability against chloride attacks and abrasion. Abe et al. ${ }^{10)}$ proposed a composite slab system, consisting of a concrete slab cast onto a UFC permanent formwork, and also investigated punching shear failure mechanism with a RC slab and UFC permanent formwork composite structure failed in punching shear and at the same time the UFC permanent formwork separated from the composite surface. Moreover, Shibata et al. ${ }^{11)}$ discussed that the bond characteristic between concrete and UFC panels would be very important to improve the load carrying capacity and deformation performance. However, the available studies on the mechanical performance of RC beams using a UFC permanent formwork is insufficient and the interfacial bonding between concrete and UFC has not been considered. To overcome this problems, the Ushaped UFC permanent formwork with interface shear keys and screws and bolts system has been examined.

The objective of this research is to investigate the mechanical performance of RC beams failing in shear with U-shaped UFC permanent formwork. An experimental research on the shear behavior of eight RC beams using a UFC permanent formwork was conducted in this study. This research was a first exploration of the UFC permanent formwork concept presented above. Shear behavior of RC beams using a UFC permanent formwork with considering the effect of internal surface and presence of screws and bolts has been examined. Shear capacities, crack patterns and failure mechanism were investigated. Subsequently, the effect of thickness of permanent formwork, shear span to effective depth ratio $(a / d)$ and presence of stirrup were clarified. Finally, a calculation method for evaluating the shear carried by UFC permanent formwork was proposed.

\section{MATERIALS}

In this research, self-compacting concrete, steel bars, UFC and screws and bolts were used. The following sections provide a detailed description of the each material.

\section{(1) Concrete}

Because of the presence of shear keys at the internal surface of UFC U-shaped permanent formwork, the self-compacting concrete was used in this experiment, and the details of mix proportion are summarized in Table 1. The materials used in the concrete mixes were high-early strength cement, lime stone powder, fine aggregates, coarse aggregates, viscosity improver and superplasticizer, which was high-performance air entrained (AE) water reducing agent. The designed compressive strength of 7-day age concrete was $35 \mathrm{MPa}$.

\section{(2) Steel reinforcement}

The characteristics of the tension reinforcement used in this study are shown in Table 2. A deformed PC bar whose nominal diameter: $d=21.4 \mathrm{~mm}$, the yield strength: $f_{y}=930 \mathrm{MPa}$ and the ultimate strength: $f_{u}=1080 \mathrm{MPa}$. The specifications for the PC bars are according to JIS G 3109. The deformed steel bar of $10 \mathrm{~mm}$ in diameter was arranged as compression reinforcement. The yield strength was 339 MPa.

\section{(3) UFC}

UFC is a material produced by mixing pre-mix powder of cement, silica fume, silica fine powder and silica sand in the optimum proportion with water and high performance polycarboxylic superplasticizer and steel short fiber. The volume fraction of steel short fiber ( $0.2 \mathrm{~mm}$ diameter x $15 \mathrm{~mm}$ length) was $2 \%$. Table 3 shows the mix proportion of UFC.

\section{(4) Screws and Bolts}

The stainless steel with SUS304 specification 
Journal of Japan Society of Civil Engineers, Ser.

E2 (Materials and Concrete Structures), Vol. 69, No. 1, 67-81, 2013.

Table 1 Mix proportion of concrete.

\begin{tabular}{|c|c|c|c|c|c|c|c|c|c|}
\hline \multirow[b]{2}{*}{$\begin{array}{l}G_{\max } \\
(\mathrm{mm})\end{array}$} & \multirow[b]{2}{*}{$\begin{array}{c}\text { Water } \\
\text { Cement } \\
\text { Ratio } \\
(\%)\end{array}$} & \multirow[b]{2}{*}{$\begin{array}{c}\text { Fine } \\
\text { Aggregate } \\
\text { Ratio } \\
(\%)\end{array}$} & \multicolumn{7}{|c|}{ Unit weight $\left(\mathrm{kg} / \mathrm{m}^{3}\right)$} \\
\hline & & & $\begin{array}{c}\text { Water } \\
\qquad W\end{array}$ & $\begin{array}{c}\text { Cement } \\
\text { C }\end{array}$ & $\begin{array}{c}\text { Lime } \\
\text { stone } \\
\text { powder } \\
L\end{array}$ & $\begin{array}{c}\text { Fine } \\
\text { aggregate } \\
S\end{array}$ & $\begin{array}{c}\text { Coarse } \\
\text { aggregate } \\
G\end{array}$ & $\begin{array}{c}\text { Super- } \\
\text { plasticizer } \\
S P\end{array}$ & $\begin{array}{c}\text { Viscosity } \\
\text { improver } \\
V\end{array}$ \\
\hline 13 & 57 & 45 & 165 & 292 & 249 & 718 & 857 & $W \times 1.5 \%$ & $C \times 0.15 \%$ \\
\hline
\end{tabular}

$G_{\max }=$ maximum size of coarse aggregate

Table 2 Yield strength of reinforcements.

\begin{tabular}{|c|c|c|}
\hline Term & Type & $\begin{array}{c}\text { Yield } \\
\text { strength } \\
\text { (MPa) }\end{array}$ \\
\hline Tension reinforcement & D22 SBPD930 & 930 \\
\hline Compression reinforcement & D10 SD295 & 339 \\
\hline
\end{tabular}

grade screws and bolts with $10 \mathrm{~mm}$ diameter were used in this research. The yield strength and the tensile strength were 240 and $568 \mathrm{MPa}$, respectively.

\section{(5) UFC permanent formwork}

The U-shaped UFC permanent formwork was fabricated in advance before casting of concrete. Plywood which is designed for concrete casting was used to build a mold for casting the U-shaped UFC formwork. The plywood was cut and made to form a pattern of shear keys. The flowability performance of UFC is achieved to exhibit a flow value (JIS-R5202.11) with around $260 \mathrm{~mm}$ for the material temperature of $20-25^{\circ} \mathrm{C}$ even for including the steel fiber by $2 \%$ in volume. Therefore, it turns to be able to cast into the very thin complicated-shaped shell mold. After mixed materials have hardened, it undergoes the stream curing at $90^{\circ} \mathrm{C}$ for 48 hours.

\section{EXPERIMENTAL PROGRAM}

\section{(1) Experimental parameters and specimens}

To investigate shear behavior of RC beams with U-shaped UFC permanent formwork, nine specimens were prepared. Four-point bending tests were conducted. The summary of test variables and details of specimens are provided in Table $\mathbf{4}$ and Fig. 1. The experimental cases can be classified into four series. Series-I was to examine the effect of shear keys on the internal surface and presence of screws and bolts. Series-II investigated the effect of thickness of UFC permanent formwork. Series-III examined the effect of shear span to effective depth ratio $(a / d)$. And Series-IV was for the presence of stirrups. Figure 1 shows dimension, arrangement of reinforcing steel bar and cross section of all specimens. As constant variables for all specimens, effective depth, width, height and tension reinforcement ratio are $d=220 \mathrm{~mm}, b=250 \mathrm{~mm}, h=300 \mathrm{~mm}$ and
Table 3 Mix proportions of UFC.

\begin{tabular}{|c|c|c|c|c|}
\hline \multirow{2}{*}{$\begin{array}{c}\text { Flow } \\
(\mathrm{mm})\end{array}$} & \multicolumn{4}{|c|}{ Unit weight $\left(\mathrm{kg} / \mathrm{m}^{3}\right)$} \\
\cline { 2 - 5 } & Water & $\begin{array}{c}\text { Premix } \\
\text { binder }\end{array}$ & $\begin{array}{c}\text { Steel } \\
\text { fiber }\end{array}$ & $\begin{array}{c}\text { High performance } \\
\text { water reducing agent }\end{array}$ \\
\hline $260 \pm 20$ & 180 & 2254 & 157 & 24 \\
\hline
\end{tabular}

$p_{w}=1.41 \%$, respectively. In order to control a shear span of failure, a number of stirrups were differently provided in each span.

First, the effect of shear keys at the internal surface between UFC formwork and inside RC and the presence of screws and bolts were considered in Series-I, in which the name of specimens listed in Table 4 corresponds to them. Ref was the reference specimen in which the U-shaped UFC formwork was not used. UFC20-S was the specimen which had smooth surface on the internal surface. UFC20$\mathrm{K}$ was the specimen in which shear keys at the internal surface between UFC formwork and inside RC were provided. Smooth surface at the internal surface and screws and bolts were provided in UFC20-SB. On the other hand, UFC20-KB was the specimen, which had shear keys on the internal surface between UFC formwork and inside RC, and screws and bolts were provided.

In Series-II, total cross section of the specimen was same, but the thickness of UFC formwork was increased to $30 \mathrm{~mm}$ in UFC30-KB in both sides and bottom part.

Series-III consisted of three specimens with different shear span. Effective depth of the beams was same, but the shear span was varied. The original specimen was UFC20-KB with $a / d$ was 3.27. The $a / d$ of UFC20-KB-ad1 and UFC20-KB-ad21 were 1.00 and 2.16, respectively. Figure 2 illustrates the details of specimens. The results of UFC20-KB-ad1 and UFC20-KB-ad21 are discussed with UFC20KB.

In Series-IV, the size of the specimen was same as Series-I, and shear keys and bolts were provided. The stirrups were provided in UFC20-KB-r, with stirrup ratio was $0.28 \%$ and spacing was $240 \mathrm{~mm}$.

\section{(2) Fabrication of the specimens}

The specimen consists of two parts. One is a Ushaped UFC permanent formwork which has been 
Table 4 List of the experimental cases.

\begin{tabular}{|c|l|c|c|c|c|c|c|}
\hline No. & Name & $\begin{array}{c}\text { Thickness of } \\
\text { UFC formwork } \\
(\mathrm{mm})\end{array}$ & $\begin{array}{c}\text { Internal } \\
\text { Surface }\end{array}$ & $\begin{array}{c}\text { Screw } \\
\text { and bolt }\end{array}$ & $\begin{array}{c}\text { Stirrup } \\
\text { ratio } \\
(\%)\end{array}$ & a/d & Series \\
\hline 1 & Ref & - & - & - & 0 & 3.27 & I, II \\
\hline 2 & UFC20-K & 20 & Shear keys & - & 0 & 3.27 & \multirow{2}{*}{ I } \\
\hline 3 & UFC20-SB & 20 & Smooth & Provided & 0 & 3.27 & \\
\hline 4 & UFC20-S & 20 & Smooth & - & 0 & 3.27 & I, II, III, IV \\
\hline 5 & UFC20-KB & 20 & Shear keys & Provided & 0 & 3.27 & II \\
\hline 6 & UFC30-KB & 30 & Shear keys & Provided & 0 & 3.27 & IV \\
\hline 7 & UFC20-KB-r & 20 & Shear keys & Provided & 0.28 & 3.27 & III \\
\hline 8 & UFC20-KB-ad1 & 20 & Shear keys & Provided & 0 & 1.00 & III \\
\hline 9 & UFC20-KB-ad21 & 20 & Shear keys & Provided & 0 & 2.16 & 0 \\
\hline
\end{tabular}

$$
\text { Formwork thickness Internal surface Bolt and screw }
$$

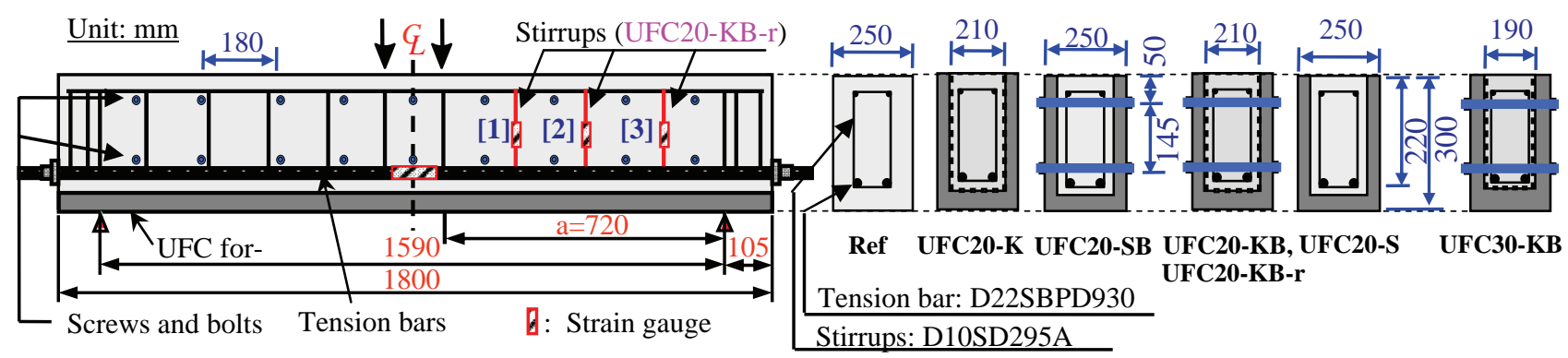

Fig. 1 Detail of specimens.

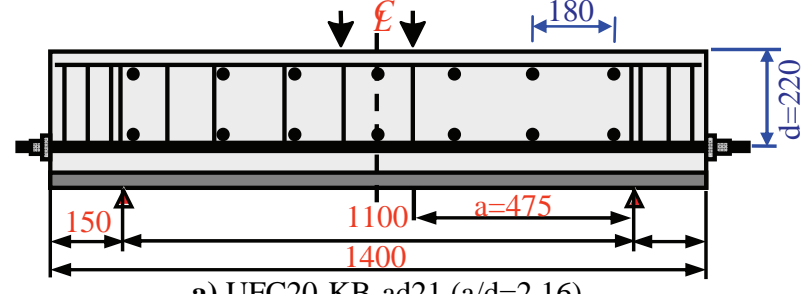

a) UFC20-KB-ad21 (a/d=2.16)

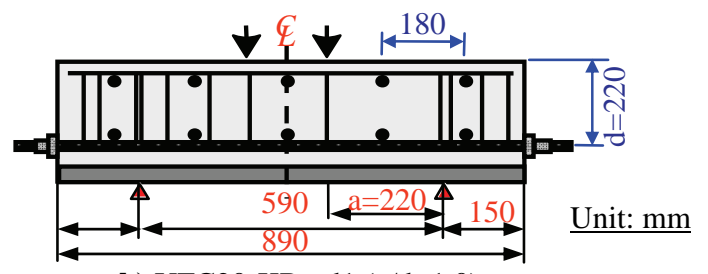

b) UFC20-KB-ad1 (a/d=1.0)

Fig. 2 Detail of specimens in Series-III.

fabricated in advance. The other is reinforced concrete which is cast in the formwork to make a structural component. For example, in the case of UFC20-KB, after UFC formwork has been already fabricated, reinforcing bars were arranged and put in a UFC formwork, then, screws and bolts were provided. Location of the screws and bolts are shown in Fig. 1. After that concrete was cast and cured for 7 days.

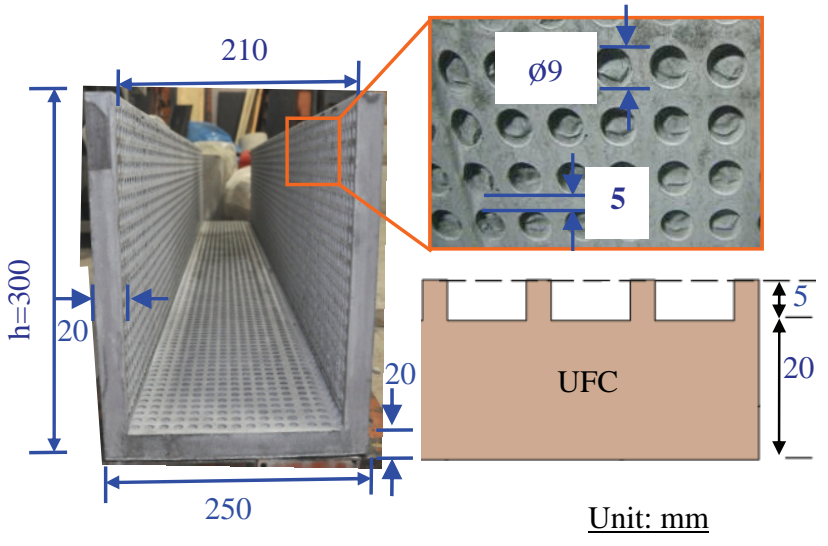

Fig. 3 Detail of UFC formwork and shear keys.

\section{(3) Loading method}

Specimens were subjected to a four-point bending with the load applied to both the UFC and RC at the same time. To satisfy the simple supporting condition, specimens were placed on the roller supports. Teflon sheets and grease were inserted between the specimen and supports in order to prevent the horizontal friction. At the loading points on the top surface of the specimen, steel plates with $50 \mathrm{~mm}$ width, steel rollers and load distribution beam were placed. The loading rate is about $0.15-0.25 \mathrm{kN}$ per second. 


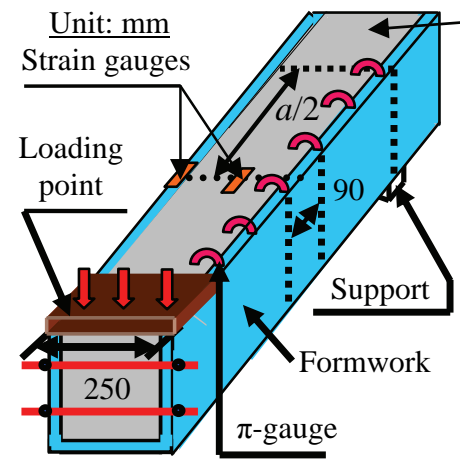

(a) Measurements items

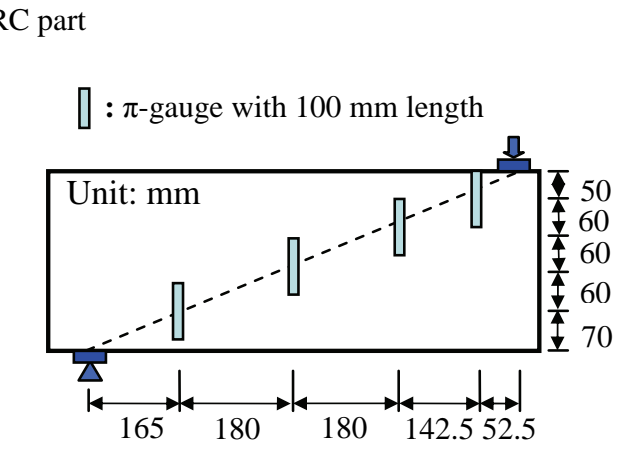

(b) Position of $\pi$-gauge on side surface

Fig. 4 Measurements and loading condition.

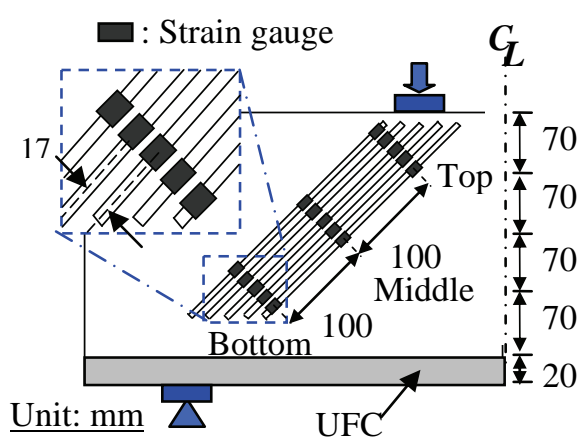

Fig. 5 Arrangement of acrylic bars.

Table 5 Mechanical properties of concrete and UFC, and the result of loading tests.

\begin{tabular}{|c|c|c|c|c|c|c|c|c|}
\hline \multirow[b]{2}{*}{ Name } & \multicolumn{2}{|c|}{$\begin{array}{l}\text { Mechanical properties } \\
\text { of concrete }\end{array}$} & \multicolumn{2}{|c|}{$\begin{array}{c}\text { Mechanical properties } \\
\text { of UFC }\end{array}$} & \multicolumn{4}{|c|}{ Results of loading test } \\
\hline & $\begin{array}{c}f_{c}^{\prime} \\
(\mathrm{MPa})\end{array}$ & $\begin{array}{c}f_{t} \\
(\mathrm{MPa})\end{array}$ & $\begin{array}{l}f_{C_{-} U F C} \\
(\mathrm{MPa})\end{array}$ & $\begin{array}{l}f_{t_{-} U F C} \\
(\mathrm{MPa})\end{array}$ & $\begin{array}{c}\text { Flexural } \\
\text { cracking load } \\
(\mathrm{kN})\end{array}$ & $\begin{array}{l}\text { Peak } \\
\text { load } \\
(\mathrm{kN})\end{array}$ & $\begin{array}{c}V_{u} \\
(\mathrm{kN})\end{array}$ & $R$ \\
\hline Ref & 32.8 & 2.1 & - & - & 45.0 & 138.0 & 69.0 & 1.0 \\
\hline UFC20-S & 43.5 & 2.5 & 194.7 & 10.1 & 105.1 & 319.6 & 159.8 & 2.32 \\
\hline UFC20-K & 36.6 & 2.7 & 191.5 & 13.9 & 90.6 & 334.6 & 167.3 & 2.42 \\
\hline UFC20-SB & 33.5 & 2.5 & 192.6 & 11.4 & 95.3 & 355.8 & 177.9 & 2.58 \\
\hline UFC20-KB & 40.4 & 2.1 & 184.2 & 11.9 & 82.1 & 384.0 & 192.0 & 2.78 \\
\hline UFC30-KB & 36.2 & 2.2 & 181.8 & 12.0 & 92.0 & 447.0 & 223.5 & 3.24 \\
\hline UFC20-KB-r & 36.4 & 2.7 & 170.5 & 12.4 & 92.6 & 427.6 & 213.8 & 3.10 \\
\hline
\end{tabular}

$f_{c}^{\prime}$ : compressive strength of concrete, $f_{t}$ : tensile strength of concrete, $f_{c_{-} U F C}^{\prime}$ : compressive strength of UFC, $f_{t_{-} U F C}$ : tensile strength of UFC, $V_{u}$ : Shear Capacity, $R$ : Ratio of shear capacity

\section{(4) Measurement items}

During the loading test, the applied load was measured. Mid-span deflection was measured by using transducers. Strain gauges were used for measuring the strain of tension steel bars at midspan and concrete on the top fiber at mid-span. The opening widths between concrete and UFC formwork were measured by using $\pi$ gauges with interval of $90 \mathrm{~mm}$ along longitudinal direction of the beams as shown in Fig. 4(a). The strain gauges were attached at the top edge of UFC formwork and RC part to check the compatibility between UFC and concrete in the longitudinal direction of the beam. The deformation of the beam was assumed symmetric with respect to the vertical axis of symmetry of the cross section of the beam. Moreover, on the side surface of UFC permanent formwork, four $\pi$-gauges were used to measure the diagonal crack opening width along the diagonal line between the loading point and support as the position is shown in Fig. $\mathbf{4}$ (b). In addition, in UFC20-KB-ad1, strains of concrete and UFC were measured by using the acrylic bars and concrete strain gauges, respectively. Figure 5 shows the arrangement of acrylic bars inside concrete. Concrete strain gauges were attached at the same position of those on acrylic bars. According to the method by Nakamura and Higai ${ }^{12)}$, acrylic bars were fixed by making dents and set at the center of the cross section width in the direction of compressive stress flow from the loading point to the supporting point. Five acrylic bars were set at $17 \mathrm{~mm}$ intervals. Three strain gauges were attached on each acrylic bar, in order to measure the strain near the loading point, center of the compressive strut and the supporting point.

\section{RESULTS AND DISCUSSIONS}

\section{(1) Shear capacities in Series-I}

Table 5 shows mechanical properties of concrete and UFC, and the result of loading tests. From Table 5, specimens can be arranged as UFC20-S, UFC20-K, UFC20-SB and UFC20-KB in order of the ratio of shear capacity $(R)$ which is a ratio of shear capacity in each specimen divided by a Ref specimen with 2.32, 2.42, 2.58 and 2.78, respectively. It indicates that by using the U-shaped UFC formwork on the cross section of a RC beam, the shear capacity increased drastically. The shear capacity of the beam with providing screws and bolts was much larger than that with only providing shear 


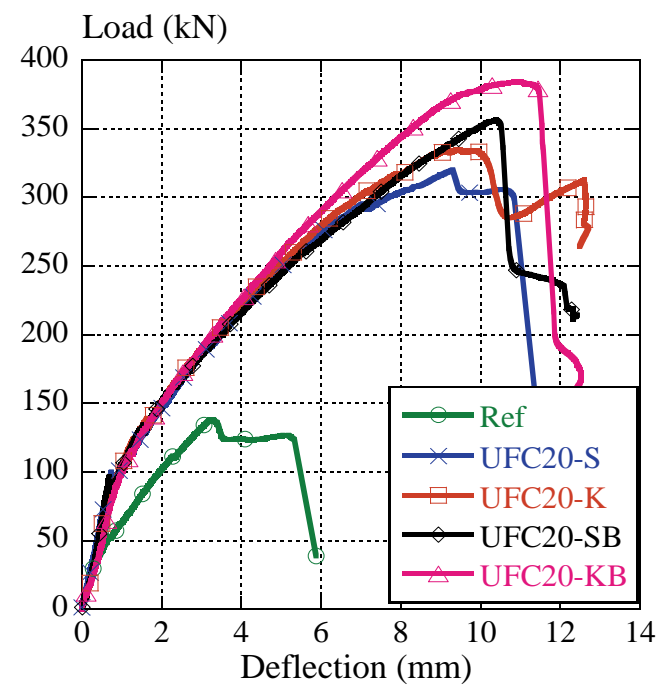

Fig. 6 Load-deflection relationships in Series-I.

keys. The shear capacity of the beam with shear keys and providing screws and bolts was the largest.

\section{(2) Load-deflection relationships and crack pat- terns in Series-I}

Figure 6 shows the relationships between the load and the mid-span deflection. The mid-span deflection was obtained by subtracting the displacements at the supporting points from the mid-span displacement. Figure 7 shows the crack patterns observed after the loading tests. For UFC20-S, UFC20-K, UFC20-SB and UFC20-KB specimens, the crack patterns of both UFC and inside RC part are shown. The bold lines in Fig. 7 represent the critical cracks. The failure process in each specimen is discussed below.

\section{a) Ref}

The flexural crack initiated at $45.0 \mathrm{kN}$. The diagonal crack initiated at the middle of test span and load dropped suddenly at the peak load $(138.0 \mathrm{kN})$ as shown in Fig. 7(a).

\section{b) UFC20-S}

The flexural cracks on UFC formwork initiated at $105.1 \mathrm{kN}$. Then, the inclined crack on UFC formwork propagated and slipping between RC and UFC permanent formwork occurred at the peak load. After the test, UFC formwork was removed and diagonal crack of inside RC part is shown in Fig. 7(b1) and (b2).

\section{c) UFC20-K}

The flexural cracks initiated when the load was $90.6 \mathrm{kN}$. At the peak load, the inclined crack located from the support to loading point propagated as shown in Fig. 7(c1) and (c2).

\section{d) UFC20-SB}

When the load reached to the peak, a number of cracks occurred as shown in Fig. 7(d1). Figure

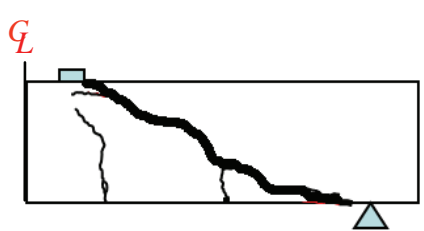

(a) Ref

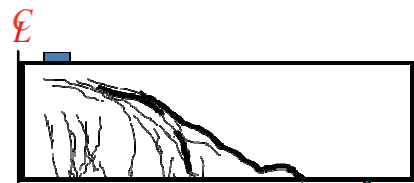

(b1) UFC20-S (UFC)

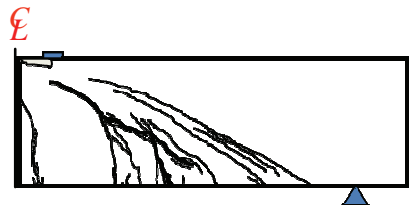

(c1) UFC20-K (UFC)

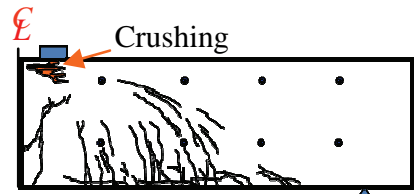

(d1) UFC20-SB (UFC) $\triangle$

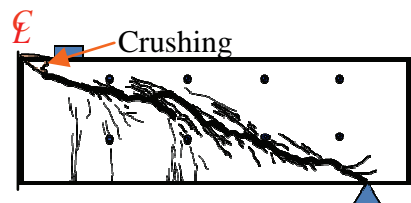

(e1) UFC20-KB (UFC)
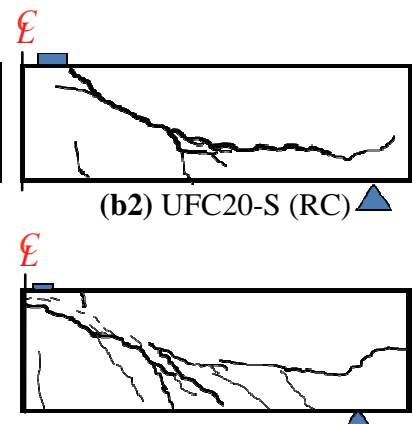

(c2) UFC20-K (RC)

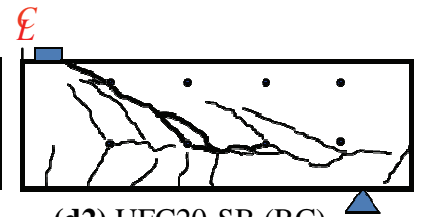

(d2) UFC20-SB (RC)

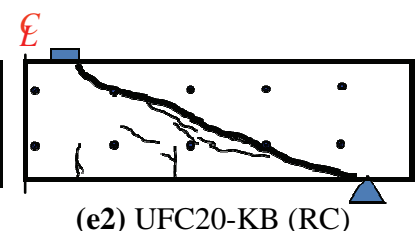

(e2) UFC20-KB (RC)
Fig. 7 Crack patterns of Series-I.

7(d2) shows the diagonal crack of inside RC part. The critical crack penetrated from a bolt to a bolt and looked very different from those in UFC.

\section{e) UFC20-KB}

At the peak load, the critical diagonal crack was propagated and widened, and the crushing of UFC under the loading point occurred as shown in Fig. 7(e1). It seems that the diagonal crack of inside RC part occurred at the same location of that in the UFC permanent formwork shown in Fig. 7(e2).

\section{(3) Shear resisting mechanism in Series-I}

The shear resisting mechanisms of UFC20-S, UFC20-K, UFC20-KB and UFC20-SB were different because of the effect of shear keys at the internal surface and the effect of screws and bolts. The shear resistance mechanisms in all specimens are explained below.

\section{a) UFC20-S}

Figure 8 shows the relationships between the load and average opening width between RC and UFC formwork on the top surface of all specimens except for Ref. Figure 9 shows the relationships between the load and strain at the top surface of RC and UFC formwork at the mid of shear span of 


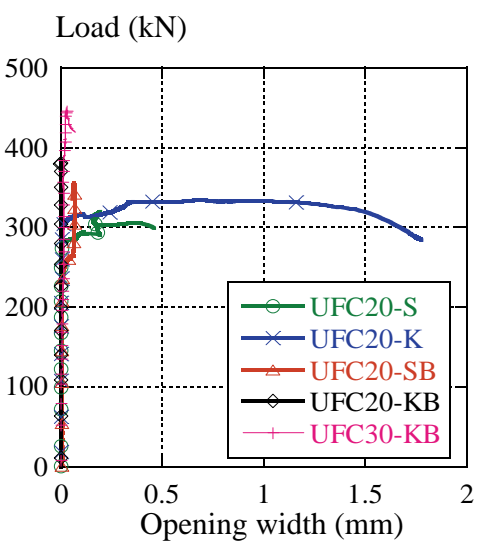

Fig. 8 Load-opening width in Series-I and II.

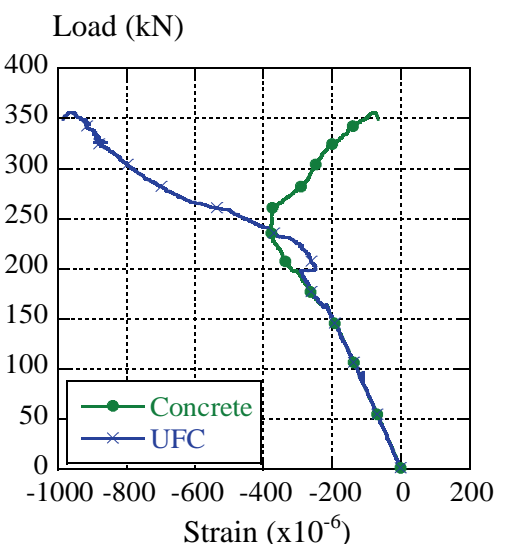

Fig. 11 Load-strain at the upper surface (UFC20-SB).
Load (kN)

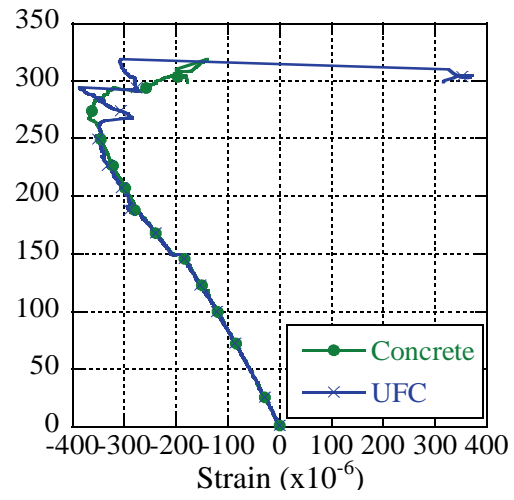

Fig. 9 Load-strain at the upper surface (UFC20-S).

Load $(\mathrm{kN})$

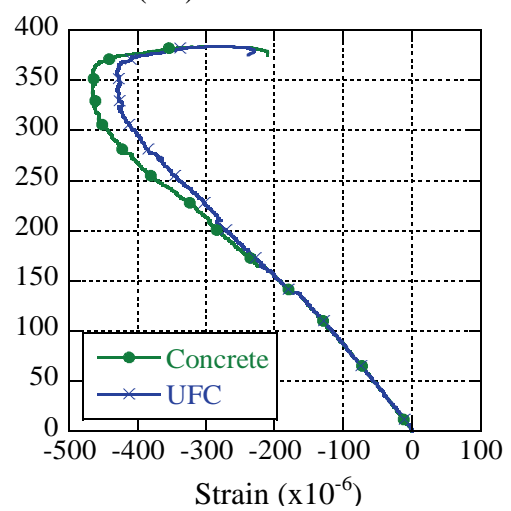

Fig. 12 Load-strain at the upper surface (UFC20-KB).
Load $(\mathrm{kN})$

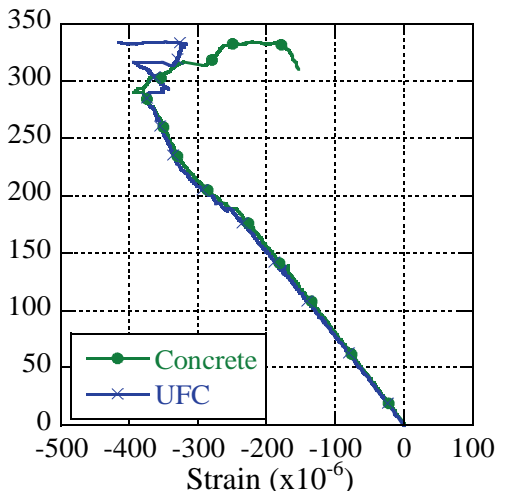

Fig. 10 Load-strain at the upper surface (UFC20-K).

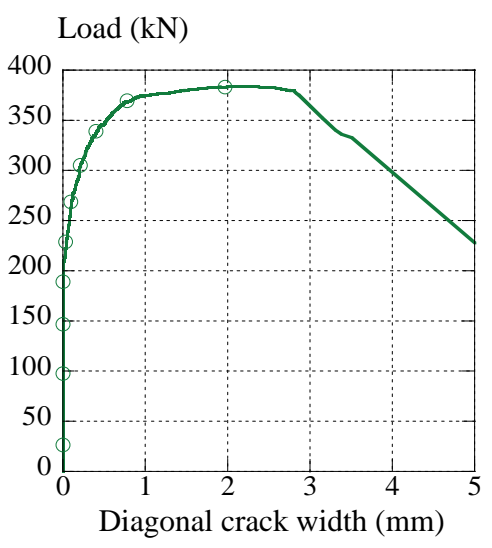

Fig. 13 Load-diagonal crack width (UFC20-KB).
UFC20-S specimen (see Fig. 4). Here, the tensile strain is shown as positive, conversely, negative shows the compressive strain. UFC formwork prevented widening of diagonal crack because of the bonding between UFC and RC. At $287.5 \mathrm{kN}$ or 90 percentage of the peak load $\left(0.9 P_{\max }\right)$, UFC formwork could not resist opening of the diagonal crack. Consequently, slipping between RC and UFC permanent formwork occurred and the UFC formwork and RC part showed different behavior after $0.9 P_{\max }$ as shown in Fig. 9.

\section{b) UFC20-K}

UFC on the side of the RC part prevented the widening of the diagonal crack through shear keys between UFC and concrete surface. The opening width between RC and UFC formwork increased drastically at $0.9 P_{\max }$ due to the lateral force from the interlocking action as shown in Fig. 8, and the UFC formwork and RC part showed different behavior after $0.9 P_{\max }$ as shown in Fig. 10.

\section{c) UFC20-SB}

In UFC20-SB specimen, as the load increased, the diagonal crack in RC part attempted to widen, but it was resisted by forces, which were generated at the top and bottom of bolts. As a result, since the forces were concentrated around the bolts, the criti- cal diagonal crack was widened and propagated to connect from a bolt to a bolt as shown in Fig. 7(d1). Moreover, the opening width between RC and UFC formwork was slightly increased at $0.7 P_{\max }$ (see Fig. 8). After that, the UFC formwork and RC part showed different behavior as shown in Fig. 11.

\section{d) UFC20-KB}

As shown in Fig. 12, the strains at the top surface of RC part and UFC formwork showed similar values. In other words, the beam had compatibility until the test finished. It is noted that the opening width between RC and UFC formwork was very small as shown in Fig. 8. As the load increased, the diagonal crack in RC part was still resisted by synergetic effect of forces which were generated at the top and bottom of screws and bolts and the shear key at the interface. Then, the main diagonal crack on UFC occurred at $0.7 P_{\max }$, while the opening width of diagonal crack was increasing as the average crack width from four measured crack widths along the diagonal crack is shown in Fig. 13. At the peak load, the load dropped and failure occurred.

In comparison, for the beam with only providing shear keys, the diagonal crack was resisted to widen by shear keys at the internal surface. On the other hand, for the beam with providing screws and bolts, 


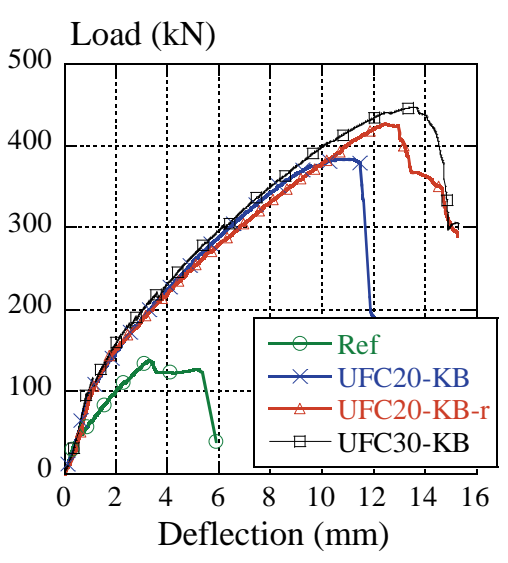

Fig. 14 Load-deflection relationships in Series-II and IV.

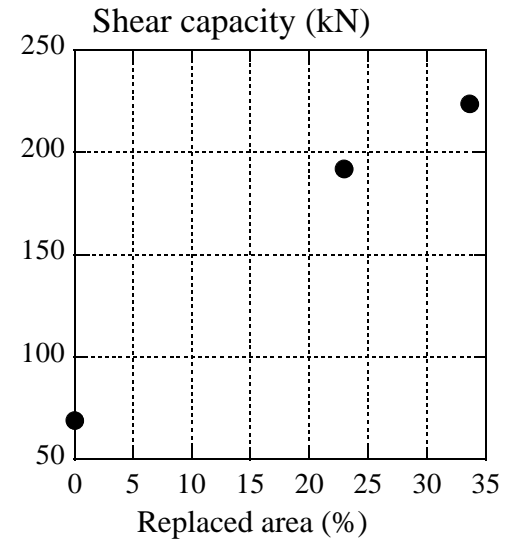

Fig. 15 Shear capacity-replaced area of UFC relationship.

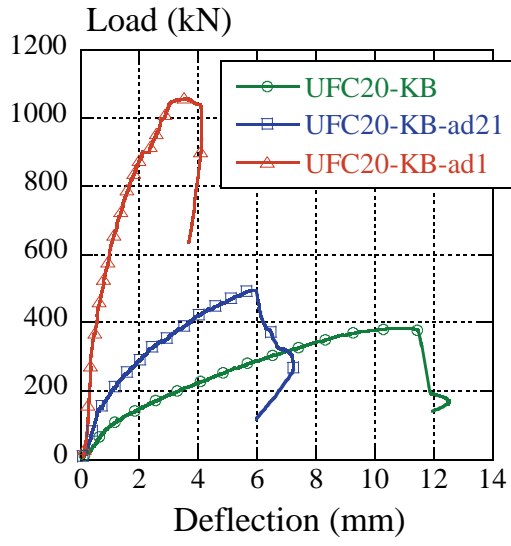

Fig. 16 Load-deflection relationships in Series-III.

Table 6 Mechanical properties of concrete and UFC, and the result of loading tests of Series-III.

\begin{tabular}{|l|c|c|c|c|c|c|c|c|}
\hline \multirow{2}{*}{ Name } & \multicolumn{2}{|c|}{$\begin{array}{c}\text { Mechanical } \\
\text { Properties of concrete }\end{array}$} & \multicolumn{2}{|c|}{$\begin{array}{c}\text { Mechanical } \\
\text { Properties of UFC }\end{array}$} & \multicolumn{4}{|c|}{ Results of loading test } \\
\cline { 2 - 9 } & $f_{c}^{\prime}$ & $f_{t}$ & $f_{c_{-} \text {UFC }}$ & $f_{t_{-} U F C}$ & $\begin{array}{c}\text { Flexural } \\
\text { cracking } \\
\text { load } \\
(\mathrm{MPa})\end{array}$ & $\begin{array}{c}\text { Peak } \\
\text { load } \\
(\mathrm{MPN})\end{array}$ & $\begin{array}{c}V_{u} \\
(\mathrm{MPN})\end{array}$ & $\begin{array}{c}\text { Failure } \\
\text { mode }\end{array}$ \\
\hline UFC20-KB & 40.4 & 2.1 & 184.2 & 11.9 & 82.1 & 384.0 & 192.0 & $\begin{array}{c}\text { Diagonal } \\
\text { tension }\end{array}$ \\
\hline UFC20-KB-ad21 & 33.1 & 2.2 & 182.7 & 12.6 & 142.8 & 496.2 & 248.1 & $\begin{array}{c}\text { Shear } \\
\text { compression }\end{array}$ \\
\hline UFC20-KB-ad1 & 30.6 & 2.3 & 177.8 & 10.8 & 334.2 & 1058.6 & 529.3 & $\begin{array}{c}\text { Shear } \\
\text { compression }\end{array}$ \\
\hline
\end{tabular}

$f_{c}{ }_{c}$ : Compressive strength of concrete, $f_{t}$ : Tensile strength of concrete, $f_{C_{-} U F C}$ : Compressive strength of UFC, $f_{t_{-} U F C}$ : Tensile strength of UFC, $V_{u}$ : Shear Capacity

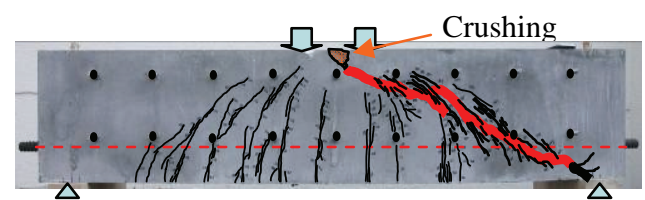

(a1) UFC20-KB (UFC)

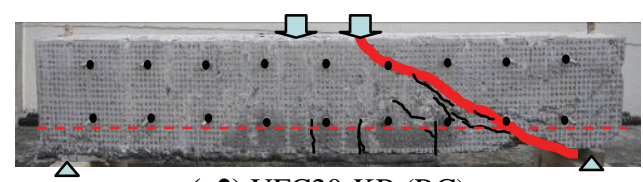

(a2) UFC20-KB (RC)

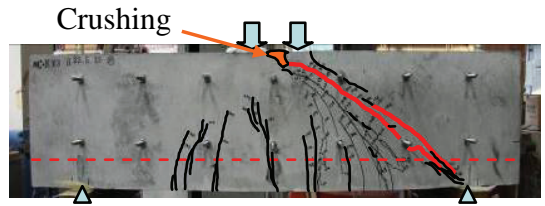

(b1) UFC20-KB-ad21 (UFC)

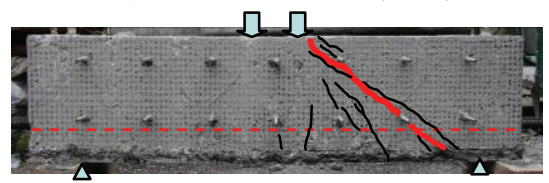

(b2) UFC20-KB-ad21 (RC)

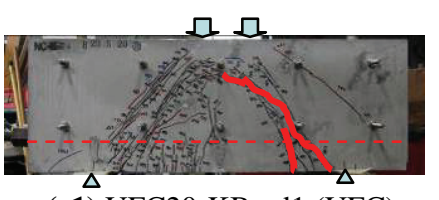

(c1) UFC20-KB-ad1 (UFC)

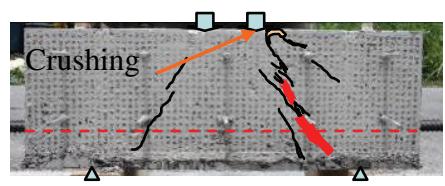

(c2) UFC20-KB-ad1 (RC)

Fig. 17 Crack patterns (Series-III).

resisting forces are transferred effectively by screws and bolts. Therefore, by combination of both screws and bolts and shear keys, the synergetic action occurred. Consequencely, the compatibility and efficiency bonding system between UFC formwork and inside RC part of the beam were shown and the shear resistance mechanism became effective. From the above reason, the UFC formwork with shear keys at the internal surface and screws and bolts system were used in the latter series.

\section{(4) Effect of thickness of permanent formwork}

The influence of thickness of UFC formwork is discussed based on the experimental results of Ref,
UFC20-KB and UFC30-KB specimens in Series-II.

From Table 5 and Fig. 14, specimens can be arranged as UFC20-KB and UFC30-KB in order of enhancement ratio of shear capacity $(R)$. Also, Fig. 15 shows that with replacement percentages of UFC formwork per total cross section area of beams, the shear capacity increased by 0, 22.9 and $33.6 \%$, and the actual shear capacity of each case was $69,192.0$ and $223.5 \mathrm{kN}$, respectively. It indicates that the shear capacity of RC beams with using U-shaped UFC permanent formwork increased drastically with increasing in thickness of formwork but it is not proportional. It is because the crack opening width between concrete and UFC slightly increased 


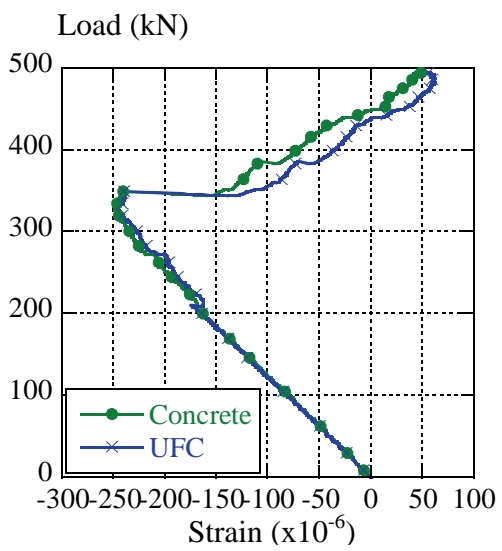

Fig. 18 Load-strain at the upper surface (UFC20-KB-ad21).

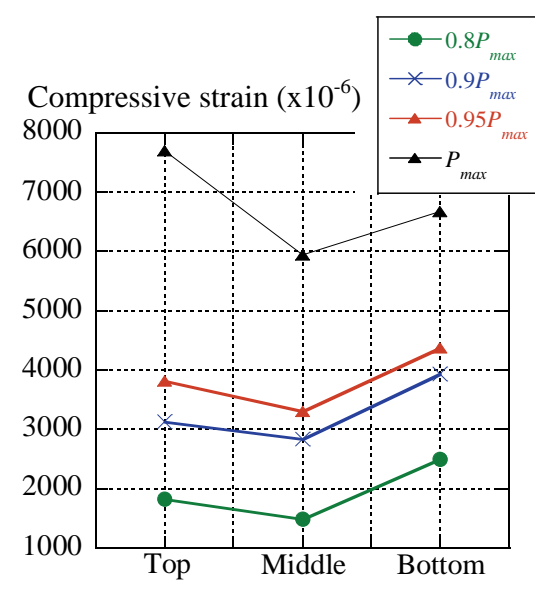

Fig. 19 Maximum compressive strain of concrete.

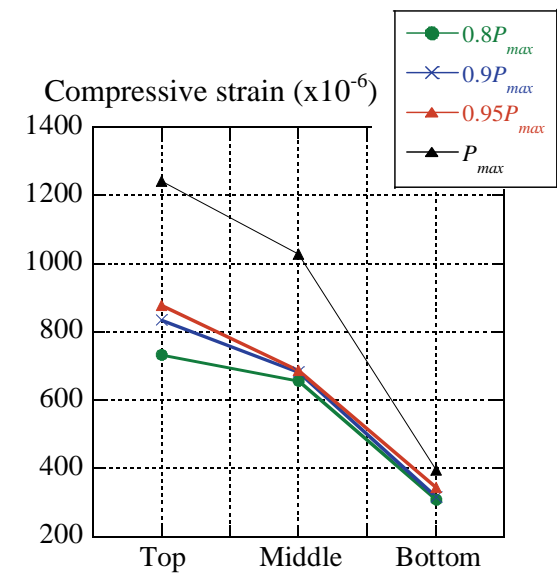

Fig. 20 Maximum compressive strain of UFC.

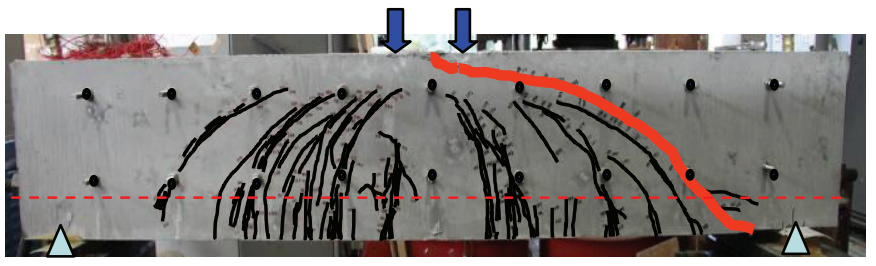

(a) UFC

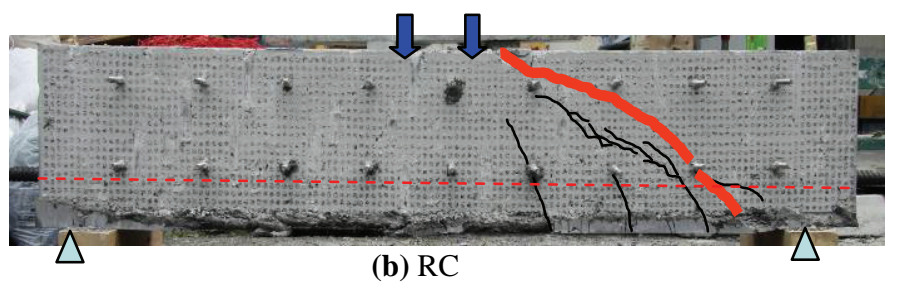

Fig. 21 Crack patterns of UFC20-KB-r.

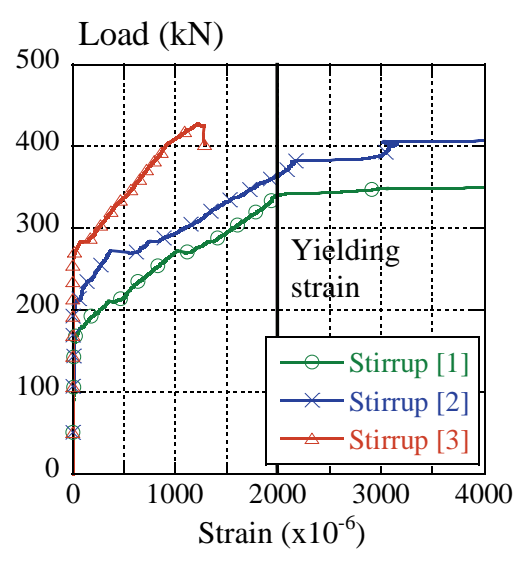

Fig. 22 Load-stirrup strain relationships. compared to UFC20-KB as shown in Fig. 8 and the shear transfer from the internal surface decreased. Therefore, the shear capacity slightly decreased.

In UFC30-KB specimen, the failure pattern was the same as observed in UFC20-KB specimen. The shear resisting mechanism of UFC30-KB was also the same as observed in UFC20-KB specimen as already explained. Therefore, even if the thickness of formwork increased, shear keys and screws and bolts system could contribute the compatibility and sufficient bonding between UFC formwork and RC part.

\section{(5) Effect of shear span to effective depth ratio $(a / d)$}

a) Load-deflection relationships and crack patterns

Figure 16 shows the relationships between the load and the mid-span deflection and Table 6 shows the experimental results in Series-III. Figure 17 shows the crack patterns of UFC20-KB-ad21, UFC20-KB-ad1 and UFC20-KB which the first two specimens failed in shear compression failure mode.

In UFC20-KB-ad21 specimen, the diagonal crack on the UFC formwork initiated at $347.3 \mathrm{kN}$ but the load was still increasing. Then, crushing of UFC under the loading point occurred at the peak load as shown in Fig. 17(b1). Figure 17(b2) shows the diagonal crack of inside RC part.

In UFC20-KB-ad1 specimen, the flexural crack on the UFC formwork initiated at $334.2 \mathrm{kN}$. After that, many cracks propagated in the direction from the support to the loading point with increasing in load as shown in Fig. 17(c1). After the loading test, the debonding failure of RC and UFC formwork and the crushing of inside RC part under the loading point was observed as shown in Fig. 17(c2).

b) Shear resisting mechanism of UFC20-KBad21

Although a diagonal crack on UFC formwork initiated, the diagonal tension failure did not occur since UFC prevented widening of diagonal crack inside RC part. Consequently, the compressive stress acted above the diagonal crack. As a result, the top fiber strains of both UFC and concrete were changed into the reverse direction as shown in Fig. 18. The flexural tension stress occurred at the upper edge of both UFC and RC. After that, the load 
Table 7 Comparison of the weight using experimental results.

\begin{tabular}{|l|c|c|c|c|c|}
\hline \multicolumn{1}{|c|}{ Name } & $\begin{array}{c}V_{c} \\
(\mathrm{kN})\end{array}$ & $\begin{array}{c}b_{w} \\
(\mathrm{~mm})\end{array}$ & $\begin{array}{c}W_{R C} \\
(\mathrm{~kg})\end{array}$ & $\begin{array}{c}W_{\text {UFC }} \\
(\mathrm{kg})\end{array}$ & $\begin{array}{c}R_{\mathrm{w}} \\
(\%)\end{array}$ \\
\hline UFC20-S & 159.8 & 784.2 & 935.2 & 298.1 & 68.1 \\
\hline UFC20-K & 167.3 & 915.6 & 1091.8 & 298.1 & 72.7 \\
\hline UFC20-SB & 177.9 & 1049.4 & 1251.4 & 298.1 & 76.2 \\
\hline UFC20-KB & 192.0 & 1071.7 & 1277.9 & 298.1 & 76.7 \\
\hline UFC30-KB & 223.5 & 1420.5 & 1693.9 & 298.1 & 82.4 \\
\hline
\end{tabular}

$W_{R C}=$ Weight of normal RC beams, $W_{U F C}=$ Weight of composite beams, $R_{w}=$ Rate of reduction $\left(=\left(W_{R C}-W_{U F C}\right) \times 100 / W_{R C}\right)$

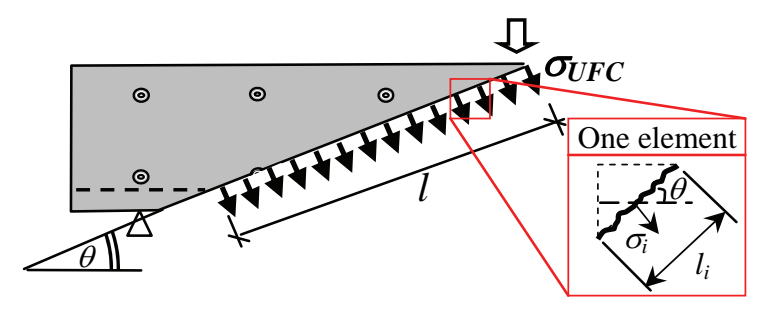

Fig. 23 Shear carrying model for UFC formwork.

reached to the peak because of the crushing of UFC near the loading point as shown in Fig. 17(b1).

From the descriptions above, it can be said that when the $a / d$ ratio changed from 3.27 to 2.16 , the failure mode changed from the diagonal tension failure to the shear compression failure because of the compression stress acted above the diagonal crack and crushing of the UFC occurred near the loading point.

c) Compressive strain of concrete in the strut formation of UFC20-KB-ad1

UFC20-KB-ad1 also failed in the shear compression mode. The failure mechanism was examined by using the strains measured in the compressive strut of both concrete and UFC.

Figures 19 and 20 show the development of the maximum compressive strain of concrete near the loading point (Top), center of the strut (Middle) and near the supporting point (Bottom) of concrete and UFC, respectively. In both concrete and UFC, compressive strains increased drastically near the peak load because the compression struts were formed in both concrete and UFC formwork. Therefore, the compressive strains reached ultimate strain and crushing of concrete occurred. It should be noted that the distribution of compressive strain of both concrete and UFC seems to be different. This is because the compatibility between RC and UFC permanent formwork cannot be secured.

\section{(6) Effect of stirrups}

Figure 14 shows the load-deflection relationships of UFC20-KB and UFC20-KB-r specimen. From Table 5, in order of enhancement ratio of shear capacity $(R)$, specimens can be arranged as UFC20-
KB and UFC20-KB-r with 2.78 and 3.10, respectively. The cracking process of UFC20-KB-r was similar to UFC20-KB and UFC30-KB as explained above. The crack patterns of UFC20-KB-r are shown in Fig. 21(a) and (b).

Figure 22 shows the relationship between the load and stirrup strain. Stirrup [1], [2] and [3] are corresponding to those in Fig. 1. Strains of stirrup [1] and [2] reached the yielding strain before the peak load. It indicated that the opening of diagonal crack in concrete was resisted by UFC formwork and stirrups, and both still carried the load until the peak load. Hence, since the stirrups were provided in RC part, the shear capacity of the beams was increased.

In comparison, the shear resisting and behavior of UFC20-KB-r was the same as that of UFC20-KB and UFC30-KB as mentioned above. When stirrups were provided, compatibility and efficient bonding of RC and UFC formwork by using shear keys and bolts can be secured.

\section{(7) Weight reduction compared to normal RC beams}

Normal RC beams that have the same load carrying capacity as specimen with UFC permanent formwork were designed in order to examine the level of weight reduction of the member. The characteristics of designed RC beams are the same as in the RC beams with U-shaped UFC formwork as shown in Fig.1 and described in section 3 (1). The shear carrying capacity of normal RC beams can be obtained from Eq. (1) ${ }^{13)}$.

$$
V_{c}=0.2\left(f_{c}^{\prime}\right)^{\frac{1}{3}}\left(p_{w}\right)^{\frac{1}{3}}\left[\frac{1000}{d}\right]^{\frac{1}{4}}\left[0.75+\frac{1.4}{a / d}\right] b_{w} d
$$

where, $V_{c}$ is the shear capacity of normal RC beams without stirrups $(\mathrm{kN}), f_{c}^{\prime}$ is compressive strength of concrete (MPa), $p_{w}$ is tension reinforcement ratio (\%), $b_{w}$ is web thickness (mm) and $d$ is effective depth (mm). 
Table 8 Experimentally observed and calculation obtained shear carried by UFC formwork.

\begin{tabular}{|c|c|c|c|c|c|c|c|c|c|}
\hline Specimens & $\begin{array}{c}t \\
(\mathrm{~mm})\end{array}$ & $\begin{array}{c}\theta \\
\left.{ }^{\circ}\right)\end{array}$ & $\begin{array}{c}f_{t-U F C} \\
(\mathrm{MPa})\end{array}$ & $\begin{array}{c}\bar{\sigma} \\
(\mathrm{MPa})\end{array}$ & $\begin{array}{c}V_{U F C \text {-exp }} \\
(\mathrm{kN})\end{array}$ & $\begin{array}{c}V_{\text {UFC-cal1 }} \\
(\mathrm{kN})\end{array}$ & $\begin{array}{c}V_{\text {UFC-cal2 }} \\
(\mathrm{kN})\end{array}$ & $\begin{array}{c}V_{U F C \text {-exp }} \\
/ V_{U F C \text {-cal1 }}\end{array}$ & $\begin{array}{c}V_{U F C \text {-ex }} \\
/ V_{U F C \text {-cal2 }}\end{array}$ \\
\hline UFC20-KB & 20 & 22.1 & 11.9 & 3.8 & 127.3 & 297.0 & 118.8 & 0.43 & 1.07 \\
\hline UFC30-KB & 30 & 21.0 & 12.0 & 5.0 & 160.9 & 375.0 & 156.3 & 0.43 & 1.03 \\
\hline UFC20-KB-r & 20 & 25.3 & 12.4 & 4.0 & 102.7 & 319.6 & 103.0 & 0.32 & 1.00 \\
\hline
\end{tabular}

$t$ : thickness of UFC permanent formwork, $\theta$ : angle of diagonal crack measured from the experiment, $f_{-} U F C$ : tensile strength of UFC, $\bar{\sigma}$ :the average of tensile stress obtained from tension softening curve, $V_{U F C \text {-exp }}$ : experimental value of shear carried by UFC perma-

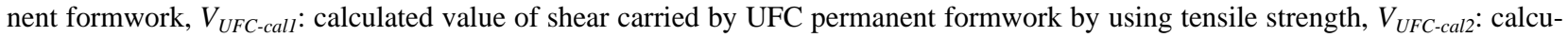
lated value of shear carried by UFC permanent formwork by using tensile stress obtained from tension softening curve.

By setting the value of $V_{c}$ corresponding to the half of the load carrying capacity of composite beams from the experiments, the width of beams $\left(b_{w}\right)$, was obtained. Thus, the width and weight of RC beams with the same load carrying capacity as composites beams were determined. From the densities of RC and UFC $\left(2.5 \mathrm{t} / \mathrm{m}^{3}\right)$, the weights of the normal RC $\left(W_{R C}\right)$ and composite beams $\left(W_{U F C}\right)$ were compared. The rate of reduction can be calculated from Eq. (2)

$$
R_{w}=\frac{\left(W_{R C}-W_{U F C}\right)}{W_{R C}} \times 100
$$

Table 7 shows the calculation results of weight reduction by using UFC permanent formwork. It was found that the weight of the members can be reduced with $68.1,72.7,76.2,76.7$ and $82.4 \%$ in UFC20-S, UFC20-K, UFC20-SB, UFC20-KB and UFC30-KB, respectively. It means that the composite beams using U-shaped UFC formworks can make a large contribution to the weight reduction of the members. As a result, performance of the member can be improved since it can take the advantage from the reduction of cross section and material volumes.

\section{INVESTIGATION ON SHEAR CARRIED BY U-SHAPED UFC PERMANENT FORMWORK}

\section{(1) Shear carried by UFC U-shaped permanent} formwork failed in diagonal tension

The shear carried by UFC permanent formwork failed in diagonal tension was investigated. The shear capacity of RC beams using UFC U-shaped permanent formwork was assumed to be the summation of shear carried by concrete, stirrups and UFC formwork. The calculation method for UFC formwork is discussed.

\section{a) Shear carried by UFC permanent formwork observed in the experiment}

The shear carried by UFC formwork in the experiment was obtained by subtracting the shear carried by concrete and stirrups from the total shear capacity observed in the loading test as calculated by Eq. (3)

$$
V_{U F C}=V_{u}-V_{c}-V_{s}
$$

where, $V_{U F C}$ is the shear carried by UFC formwork, $V_{c}$ is the shear carried by concrete, $V_{s}$ is the shear carried by stirrups.

In this research, the shear carried by concrete was determined by Eq. (1) in which only concrete part was considered. The thickness of permanent formwork was excluded from the width of beams $\left(b_{w}\right)$.

The shear carried by stirrups was obtained from the stirrup strains measured by strain gauges.

$$
V_{s}=\left\{\begin{array}{c}
A_{s} E_{s} \varepsilon_{s}\left(\varepsilon_{s}<\varepsilon_{y}\right) \\
A_{s} f_{w y}\left(\varepsilon_{s} \geq \varepsilon_{y}\right)
\end{array}\right.
$$

where, $A_{s}$ is the total sectional area of stirrup (mm), $E_{s}$ is the elastic modulus of stirrup (GPa), $\varepsilon_{s}$ is the average stirrup strain, $\varepsilon_{y}$ is the yielding strain of stirrup, $f_{w y}$ is the yielding strength of stirrup (MPa).

b) Shear carried by UFC permanent formwork obtained in the calculation

The shear carried by UFC formwork was computationally obtained based on a simplified shear carrying model. To compute the shear carried by UFC formwork, a linear crack is assumed with maintaining the angle of diagonal crack as shown in Fig. 23. The crack length of UFC permanent formwork and the angle of diagonal crack are represented by $l$ and $\theta$, respectively. The angles of diagonal cracks were measured from pictures taken at the peak load. Therefore, the shear carried by UFC formwork based on this model is given by Eq. (5). 


$$
V_{U F C}=\frac{2 \cdot t \cdot \sigma_{U F C} \cdot d}{\tan \theta}
$$

where, $t$ is the thickness of UFC permanent formwork (mm), and $d$ is effective depth (mm).

If the tensile stress $\sigma_{U F C}$ is assumed to be the tensile strength of UFC at the peak load, Eq. (5) becomes,

$$
V_{U F C}=\frac{2 \cdot t \cdot f_{t_{-} U F C} \cdot d}{\tan \theta}
$$

where, $f_{t_{-U F C}}$ is the tensile strength of UFC (MPa).

\section{c) Result of the Calculation}

Table 8 summarizes the results of experimentally observed and computationally obtained shear carried by UFC formwork by Eq. (3) and Eq. (6), respectively. In all three specimens, the shear carried by UFC formwork observed in the experiment became smaller than that obtained by Eq. (6). This is because the tensile strength was used for the stress of UFC permanent formwork $\left(\sigma_{U F C}=f_{t_{-} U F C}\right)$. From the experimental observation, the critical crack width in the UFC permanent formwork were definitely wider than crack width corresponding to the tensile strength value, for example, in the case of UFC20KB-r as shown in Fig. 24(b) and (c). According to the tension softening curve of UFC measured by Kakei et al. ${ }^{14)}$, the tensile stress $\left(\sigma_{U F C}\right)$ was modified and determined. Investigation procedures of tensile stress are shown in Fig. 24. The diagonal crack width measured by using four $\pi$-gauges along the diagonal crack (Fig. 24 (a) and (b)). Therefore, the specimen were modeled as four elements corresponding to the interval of $\pi$-gauge (Fig. 23 and 24 (a)) Then, the diagonal crack width along the shear span was transformed to the tensile stress by the tension softening curve (Fig. 24 (c)). The average tensile stress is given by the following equation.

$$
\bar{\sigma}=\frac{\sum_{i=1}^{4} \sigma_{i} l_{i}}{\sum_{i=1}^{4} l_{i}}
$$

where, $\bar{\sigma}$ is the average of tensile stress (MPa), $\sigma_{i}$ is the tensile stress obtained from tension softening curve of each element (MPa),$l_{i}$ is diagonal crack length of each element (mm)

Then, the average value of tensile stress was substituted into Eq. (5) and the shear carried by UFC permanent formwork can be calculated. The ratio of experimentally observed shear carried by UFC formwork to computationally obtained value by using the tension softening curve is shown in Table 8. In all specimens, the calculation values present the good agreement with the experimental values. Thus, the proposed model was able to give a reasonable result by using the tensile stress that obtained from the tension softening curve of UFC. This is because the diagonal crack on both UFC formwork and RC part was located almost the same position, and also the diagonal crack width of UFC was measured. It indicates that the thickness of UFC formwork greatly affects the shear carried by UFC formwork. On the other hand, in the case of specimens with stirrups, the diagonal crack width on UFC formwork did not reduce compared to the specimens without stirrup. Therefore, the effect of presence of stirrups on shear carried by UFC permanent formwork is not significant. In addition, it should be noted that the results have not been discussed up to the design level yet. Further experiment should be done in order to introduce a rational reduction factor of the tensile strength which is the empirical value of tensile

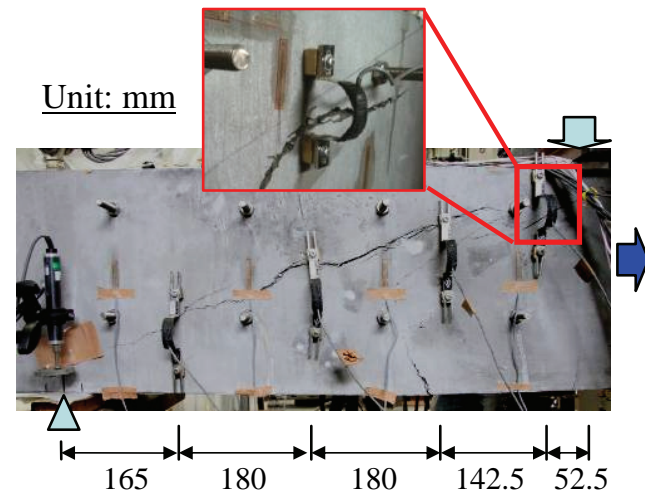

(a) Picture of test span at the peak load (UFC20-KB-r)

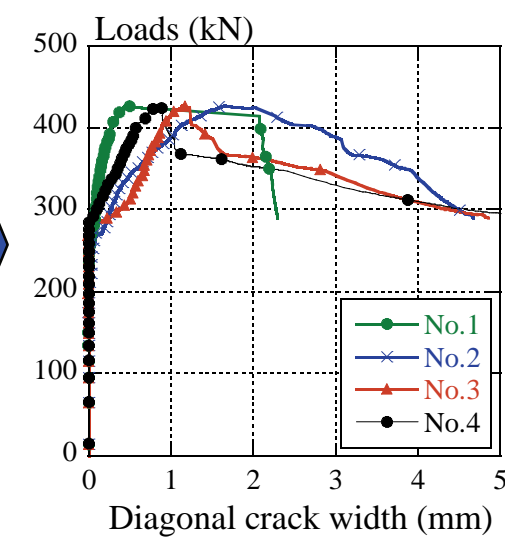

(b) Load-diagonal crack width (UFC20-KB-r)

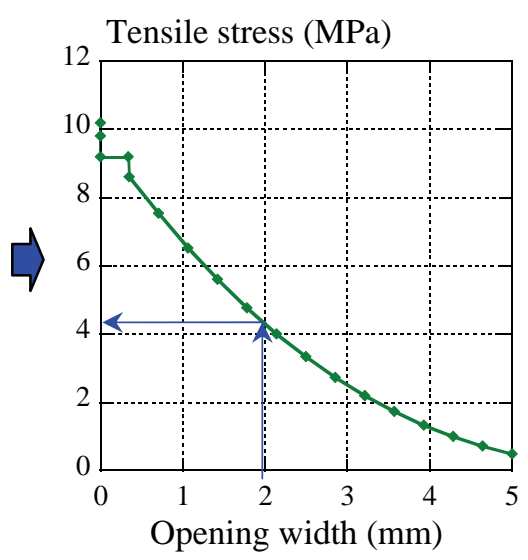

(c) Tension softening relationship of $\mathrm{UFC}^{14)}$

Fig. 24 Investigation procedures of tensile stress. 


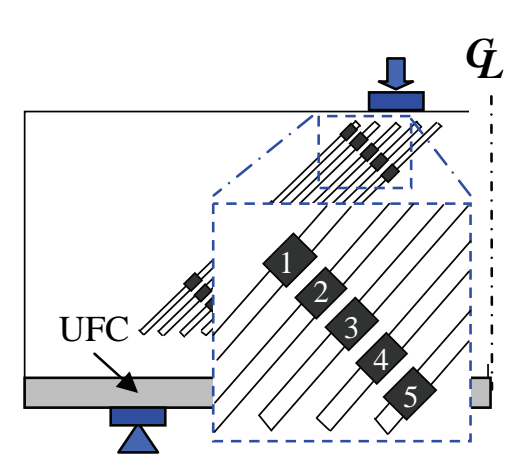

(a) The location of strain point
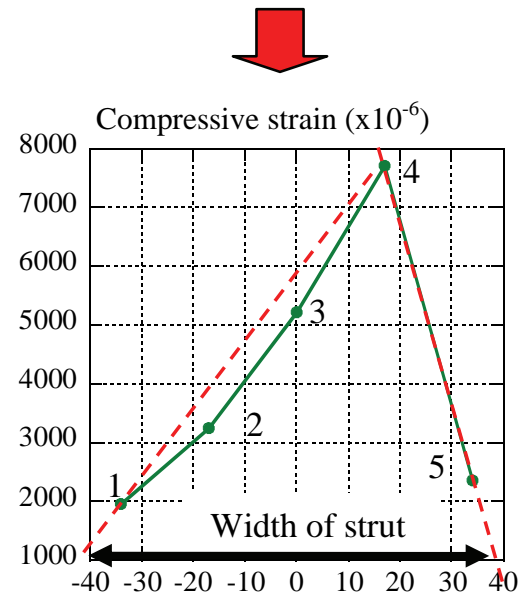

(b) The strain of acrylic bars

Fig. 25 Definition of the compressive strut.
Compressive stress $\sigma_{c}{ }^{\prime}$

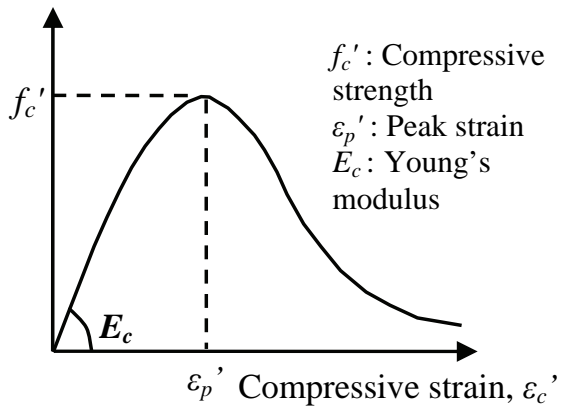

(a) Concrete(Thorenfeldt's model ${ }^{15)}$ )

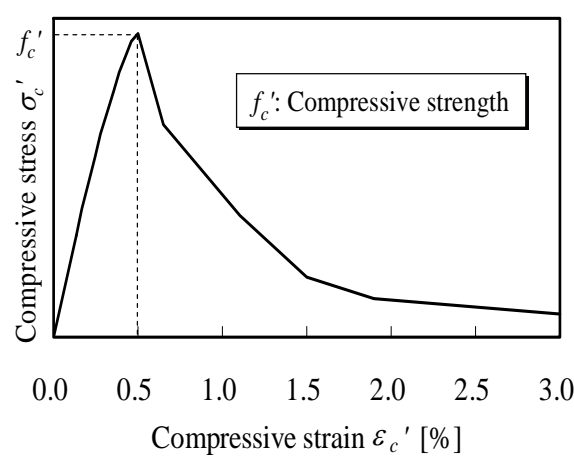

(b) UFC (Kakei’s model ${ }^{14)}$ )

Fig. 26 Stress-strain relationship for concrete and UFC in compression.

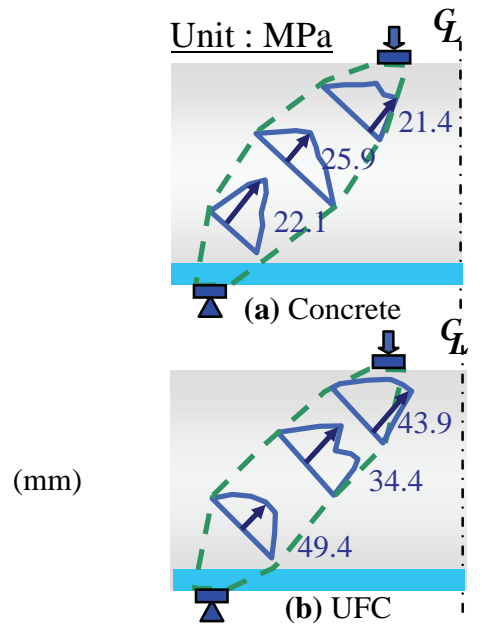

Fig. 27 Compressive stress distribution.

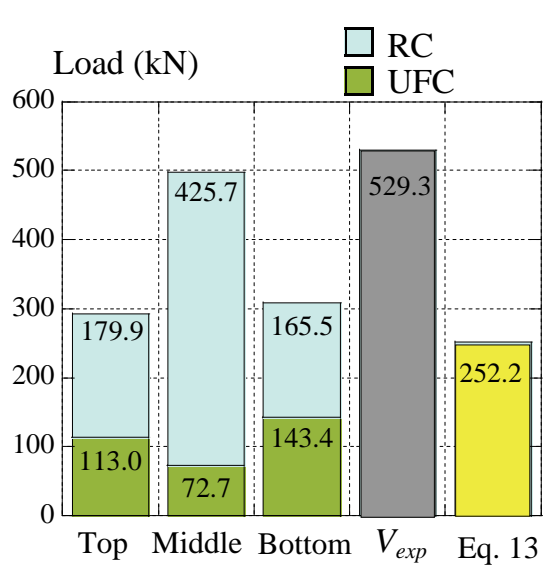

Fig. 28 Comparison of calculation and experimental value of shear resisting force. strength based on the results from the tension softening curve which can be used for design.

\section{(2) Shear carried by UFC U-shaped permanent formwork failed in shear compression}

As mentioned in 4 (5) (c), UFC20-KB-ad1 specimen failed in the shear compression failure mode. The shear carried by UFC permanent formwork failed in the shear compression failure mode is examined in this session.

a) Width of the compressive strut and the compressive stress distribution

Figure 25 presents the definition of the width of the compressive strut. The maximum strain point and both minimum strain points at $0.95 P_{\max }$ were connected by straight dashed lines as shown in Fig. 25 (b) and the width of compression strut was assumed to be the distance between the points where the strains equal to 0 as shown in Fig. 25 (b). Assuming that the strains of acrylic bars and concrete were the same and the stress state was assumed as uni-axial compression and the strain that measured on UFC was considered also in the same way. The compressive stress acting on the concrete was calculated by using the strain of acrylic bars, and the compressive stress of UFC was calculated by the strain measured by a strain gauge. From stress-strain model, the measured strains of both concrete and UFC were transformed to stress. For concrete, the stress-strain model proposed by Thorenfeldt et al. ${ }^{15)}$ shown in Fig. 26(a) was used to calculate the compressive stress. The compressive stress of concrete can be calculated from Eq. (8)

$$
\begin{gathered}
\sigma_{c}^{\prime}=\left\{\begin{array}{c}
n\left(\varepsilon_{c}^{\prime} / \varepsilon_{p}^{\prime}\right) \\
n-1+\left(\varepsilon_{c}^{\prime} / \varepsilon_{p}^{\prime}\right)^{n k}
\end{array} f_{c}^{\prime}\right. \\
k=0.8+\frac{f_{c}^{\prime}}{17} \\
0.67+\frac{f_{c}^{\prime}}{62} \quad\left(\begin{array}{cc}
1 & \left(\varepsilon_{c}^{\prime}>\varepsilon_{c}^{\prime} \leq \varepsilon_{p}^{\prime}\right)
\end{array}\right. \\
\varepsilon_{p}^{\prime}=\frac{n}{n-1} \cdot \frac{f_{c}^{\prime}}{1000 E_{c}}
\end{gathered}
$$

where, $\sigma_{c}{ }_{c}$ is the compressive stress of concrete (MPa), $\varepsilon_{p}^{\prime}$ is the strain of concrete at the maximum stress, $\varepsilon_{\mathrm{c}}^{\prime}$ is 
the compressive strain of concrete, $E_{c}$ is the modulus of elasticity of concrete (GPa).

For UFC, the stress-strain model of UFC based on the experimental results proposed by Kakei et al. ${ }^{14)}$ shown in Fig. 26(b) was used to calculate the compression stress. Figure 27(a) and (b) show the compressive stress distributions of concrete and UFC permanent formwork, respectively. In concrete part, the strut width at the middle was wider than that at near the loading point and near the support. It means that the stress concentrations were observed in both near loading and supporting points. On the other hand, the strut width of all locations in UFC formwork was not significantly different. This is because the constraint effect of UFC permanent formwork that confined RC with screws and bolts.

\section{b) Calculation of the compressive force}

The stress distributions of both concrete and UFC were converted to the vertical component of the compressive force acting on the concrete strut and UFC strut by using Eq. (12) and (13).

$$
\begin{gathered}
F_{s t}=D \times b_{i} \\
F^{\prime}=F_{s t} \times \sin \alpha
\end{gathered}
$$

where, $F_{s t}$ is the compressive force acting on the concrete or UFC strut, $D$ is the force per unit width under the compressive stress distribution curve, $b_{i}$ is the width of cross section of concrete or both of UFC formwork thickness, $F$ ' is the vertical component of $F_{s t}, \alpha$ is the angle of the strut with respect to the longitudinal axis of beams.

Figure 28 shows the comparison of the summation of calculated value $F$ ' from RC and UFC with the experimental shear capacity $V_{\text {exp }}$. Moreover, the shear capacity of normal RC deep beams that have the same cross section as UFC20-ad1 specimen (250 $\mathrm{mm}$ width) was calculated in order to examine the increase of shear capacity of the beams. The shear carrying capacity of normal RC deep beams can be obtained from Eq. (14) ${ }^{16)}$.

$$
V_{c_{-} \text {deep }}=\frac{0.244 f_{c}^{\prime 2 / 3} b_{w} d(1+3.33 r / d)\left(1+\sqrt{p_{w}}\right)}{1+(a / d)^{2}}
$$

where, $r$ is width of loading and supporting plates (mm).

From Fig. 28, it indicates that by using the Ushaped UFC permanent formwork, the shear capacity increased more than twice in case of a specimen failed by shear compression. The summation of $F$, at the middle provided the good agreement with $V_{\text {exp }}$. However, the summation of $F^{\prime}$ underestimated $V_{\text {exp }}$ at the top and bottom location. It is because the uni- axial stress-strain model (Thorenfeldt's model) was used while the compression strut of inside concrete was constrained by the UFC formwork with screws and bolts.

\section{CONCLUSIONS}

1) By using a U-shaped UFC permanent formwork, the shear carrying capacity of RC beams increased drastically. The shear carrying capacity varied depending on the internal surface between UFC formwork and RC inside and the presence of screws and bolts. This is because a UFC formwork carried shear force and resisted the opening of diagonal crack in RC part.

2) Shear resisting mechanism of $\mathrm{RC}$ beams using a UFC U-shaped permanent formwork with shear keys and bolts was investigated. By using shear keys and screwed bolts system, the sufficient compatibility behavior between UFC and RC can be formed. Since a UFC formwork prevented widening of diagonal crack inside RC by shear keys and screws and bolts, the shear capacity drastically increased.

3) With increasing in the thickness of UFC formwork, the shear capacity of RC beams with using a UFC permanent formwork increased. However, it was not proportional to the thickness of a UFC permanent formwork.

4) By providing the stirrups, the shear capacity of RC beams with using a UFC permanent formwork increased. This is because both UFC formwork and stirrups prevented widening of the diagonal crack. However, the effect of stirrups on the shear carried by a UFC formwork was very slight.

5) Failure mode of RC beams using a UFC Ushaped permanent formwork changed depending on the shear span to effective depth ratio. Compression strut was formed in a UFC formwork in the case of $a / d$ equal to 2.16 and 1.0.

6) By comparing RC beams whose cross section was replaced by a UFC U-shaped permanent formwork to normal RC beams having the same shear capacity, the weight of the member can be extremely reduced $68 \%$ to $82 \%$. Especially, the specimens with providing shear keys and screws and bolts showed the highest in the weight reduction rate.

7) The shear carried by a UFC formwork in RC beams failed in the diagonal tension mode was investigated by assuming and using the tensile stress obtained from the tension softening curve. 
The computational values showed the good agreement with the experimental values.

8) The calculation of compression forces of a UFC formwork and RC part in the specimen with $a / d$ 1.0 by using uni-axial stress-strain model did not show the good agreement near the screwed bolts. It indicated that the constraint effect of screwed bolts should be considered to evaluate the shear compressive capacity.

\section{REFERENCES}

1) Japan Society of Civil Engineers (JSCE) : Standard Specifications for Concrete Structures-2007 [Design], 2010.

2) Japan Society of Civil Engineers (JSCE) : Recommendations for Design and Construction of Ultra High Strength Fiber Reinforced Concrete Structures (Draft), JSCE Guidelines for Concrete No.9, 2006.

3) Behloul, M., Lee, K. C. and Etienne, D. : Seonyu Ductal Footbridge, fib Symposium 2004, Apr. 2004.

4) Tanaka, Y., Musya, H., Ootake, A., Shimoyama, Y. and Kaneko, O. : Design and Construction of Sakata-Mirai Footbridge using Reactive Powder Concrete, Proceedings of the first fib Congress 2002, Oct. 2002.

5) Hajar, Z., Simon, A., Thibaux, T. and Wyniecki, P. : Construction of an Ultra-High-Performance Fiber-Reinforced Concrete Thin-shell Structure over Millau Viaduct Toll Gates, fib Symposium 2004, Apr. 2004.

6) Katagiri, M., Maehori, S., Ono, T., Shimoyama, Y. and Tanaka, Y. : Physical Properties and Durability of Reactive Powder Composite Material (DuctalR), Proceedings of the first fib Congress, Session 7, pp. 133-138, Oct. 2002.

7) Kakei, T., Murata, H., Niwa, J. and Hyodo, H. : Shear Behavior of Beams with the Use of Ultra High Strength Fiber Reinforced Cement Composite, Proceedings of Japan Concrete Institute, Vol. 26, No. 2, pp. 787-792, Jul. 2004. (in
Japanese)

8) Wringley, R. G. : Permanent Formwork in Construction (CIRIA C558), CIRIA/Concrete Society, pp.13-16, 2001.

9) Shirai, K., Matsuda, K. and Tanaka, S. : Durability of UFC Formwork Left In-Place and Its Application, Proceedings of 8th International Symposium on Utilization of High-Strength and High-Performance Concrete, pp. 870-875, 2008.

10) Abe, T., Kida, T., Niimi, A., Takano, M. and Tanaka, S. : Shear Strength and Theorical Punching Shear Capacity Formulas for the Composite Surface of RC Slab using UFC Permanent Form, Journal of Structural Engineering, JSCE, Vol. 55A, pp. 1478-1487, Mar. 2009. (in Japanese)

11) Shibata, K., Kimura, T., Watanabe, K. and Niwa, J. : Strengthening Effect of UFC Embedded Form on Load Carrying Capacity of RC Column, Proceeding of the $63^{\text {rd }}$ JSCE Annual Meeting, pp. 1011-1012, Sep. 2008. (in Japanese)

12) Nakamura, H. and Higai, T. : Compressive Fracture Energy and Fracture Zone Length of Concrete, JCI-C51E Seminar on Post-Peak Behavior of RC Structures Subjected to Seismic Loads, Vol. 2, pp. 259-272, 1999.

13) Niwa, J. : The Basic of Structural Concrete, Suurikougakusha Co., Ltd, 2006. (in Japanese)

14) Kakei, T., Kawaguchi, T., Niwa, J. and Hyodo, H. : Fracture Properties of Ultra High Strength Steel Fiber Reinforced Cementitious Composites, Proceedings of Cement and Concrete, Vol. 57, pp. 230-231, 2003. (in Japanese)

15) Thorenfeldt, E., Tomaszewicz, A. and Jensen, J. J. : Mechanical Proporties of High-Strength Concrete and Application in Design, Proceeding of the Symposium on Utilization of High-Strength Concrete, Tapir, Trondheim, pp. 149-159, 1987.

16) Niwa, J. : Equation for Shear Strength of Reinforced Concrete Deep Beams Based on FEM Analysis, Proceeding of the Japan Concrete Institute $2^{\text {nd }}$ Colloquium on Shear Analysis of RC Structures, pp. 119-128, 1983. (in Japanese)

(Received June 5, 2012) 